\title{
Problems and Countermeasures of Teaching Management in Colleges and Universities
}

\author{
Lixin Fan \\ School of Humanities, Jilin Agricultural University, Changchun 130118, China
}

(E-mail:897146503@qq.com)

Key words: Teaching management; students' subjectivity; Colleges and universities

\begin{abstract}
At present, we are in a new era which calls for subjectivity and also generates subjectivity. Colleges and universities, as the institutions cultivating high level talents, should conform to the development trend of the times, pay attention to the subjectivity of the students, attach importance to the cultivation of students' ability and quality, and take to promote the development of students' subjectivity as one of the important tasks in education. Reflect on the reform process in recent decades, what is worth of being praised is that China's Colleges and universities have made great development and progress in general. But it cannot be ignored that the universities also have great potential and space in promoting the development of students' subjectivity, especially the teaching management system that takes the manager as the main body, focuses on control while ignores communication formed under the planned economy system of our country at present seriously restricts the development of students' subjectivity, ignores the subject status and personality difference of College students, so it cannot fully meet the needs of the development of students' subjectivity. This paper analyzes the problems existing of teaching management in Colleges and universities in promoting the development of students' subjectivity, and then studies the countermeasures of teaching management in Colleges and universities to promote the development of students' subjectivity, providing some reference for the teaching management in the future.
\end{abstract}

\section{Introduction}

At present, the research on the teaching management of Colleges and universities in our country is quite rich, and has produced considerable research results. The results of these studies have explored the problems of teaching management in Colleges and universities from different perspectives. In the perspective of humanistic management, Shen Yanxia's "Analysis of the implementation of humanistic management in university teaching management" pointed out that the teaching management means is too rigid, teaching mechanism lacks motivation and competition, and teaching management mode is too administrative these three problems [1]; from the point of view of cultivation of creative talents, Ou Wenjun put forward in the paper "Teaching management in Colleges and universities based on the cultivation of innovative talents" that the shortcomings of teaching management in Chinese Colleges and universities in cultivating innovative talents, related to teaching management system, management system and other problems in nine aspects [2]; in the view of overall quality management, Xiao Weichun and Zhu Xinhua's "Problems and countermeasures of teaching management in College and universities in China" exposes the five problems of the low quality of personnel, not comprehensive assessment guidance, incomplete evaluation object and so on in the teaching management in College and universities [3]; From the perspective of credit system reform, Xiangning and Luo Qingchun's "Transformation of teaching management in Colleges and universities under credit system" analyzes the problems in the implementation of the credit system of management, the level of teachers, students selecting courses, teaching quality evaluation, teaching management network system construction and other aspects [4].

In recent years, the study on the subjectivity of College students began to grow day by day, especially in the last five or six years, the development of College students' subjectivity has become the focus of attention. The majority of the research in this aspect is discussed from the ideological 
and political education, moral education, personality education level. The results of the research on the subjectivity of College students not only has a gradually increasing trend in the number, but also has some changes in the research orientation. Discussion of scholars on College students' subjectivity is no longer confined from the perspective of ideological and political education, but to a large extent closely combines the subjectivity of College students and university teaching and the cultivation of talents, and regard the cultivation of students' subjectivity as the main direction of the reform of training mode of College education. This paper studies the problems existing in the teaching management of Colleges and universities and puts forward some development countermeasures.

\section{Problems of Teaching Management in Colleges and Universities in Promoting the Development of Students' Subjectivity}

\subsection{Personnel Training Mechanism}

Table 1 is the enrollment of students' questionnaire that reform of the credit system is not in place, and there is no real realization of students' autonomous elective course.

Table 1 The questionnaire of the credit system and the independent course selection

\begin{tabular}{|c|c|}
\hline Questions & Students' answers \\
\hline $\begin{array}{l}\text { What about the implementation of credit } \\
\text { management in our school? }\end{array}$ & $\begin{array}{l}\text { We have credit for each course, and } \\
\text { different types of classes have different } \\
\text { credits. }\end{array}$ \\
\hline $\begin{array}{l}\text { Are the courses you are reading selected } \\
\text { by yourselves? }\end{array}$ & $\begin{array}{l}\text { Basically not, almost all of them are } \\
\text { arranged and fixed by school in } \\
\text { advance. }\end{array}$ \\
\hline $\begin{array}{l}\text { Are the courses you read each semester } \\
\text { arranged by your school? }\end{array}$ & $\begin{array}{l}\text { Basically. Except four selective } \\
\text { courses, other courses are arranged by } \\
\text { school. }\end{array}$ \\
\hline $\begin{array}{l}\text { Is four courses the lowest limitation? If } \\
\text { you can select several courses? }\end{array}$ & $\begin{array}{l}\text { Selecting several courses is allowed, } \\
\text { while for the courses beyond selection, } \\
\text { the credit is not calculated. }\end{array}$ \\
\hline
\end{tabular}

The credit system is a kind of flexible talent training model, which is used to measure the students' learning effect and process. It is able to adapt to the individual differences of students so that students can decide their elective courses, which is conducive to the establishment of the subject status of students in the teaching activities, stimulate students' interest in learning, and promote the development of students' personality. However, it can be seen from the interview that the university did not fully realize students' autonomous course selection. Students are still faced a series of fully arranged compulsory courses, unable to select the appropriate course according to their own interests, let alone systematically select another profession. Moreover, the school has done a mandatory requirements and restrictions on the number of courses and credits that students should have each semester, and the range for students to choose is very limited. In addition, the class time of the required courses often conflicts with the elective courses, so the selection of courses is actually the selection of the time. If there is no time, it is impossible to choose even you desire. Independent course selection is the core and key of the implementation of the credit system. If you cannot achieve autonomous elective selection, the credit system in the real sense cannot be achieved either. The final study results are basically same, unable to embody the personality characteristics [5].

\subsection{Organization and Management of Classroom Teaching}

Table 2 is a questionnaire about single teaching method, inappropriate use, and not high participation of the students. 
Table 2 Questionnaire for classroom teaching method

\begin{tabular}{cc}
\hline Questions & Students' answers \\
\hline $\begin{array}{c}\text { Is there any interactions in } \\
\text { class? }\end{array}$ & $\begin{array}{c}\text { There is interaction in class, that is, the teacher } \\
\text { asked questions, and let us answer. But the effect } \\
\text { is not good, almost no one answers. } \\
\text { Combine with the reality of students or the } \\
\text { society. } \\
\begin{array}{c}\text { Did the teachers to ask? } \\
\text { the interaction or discussion? } \\
\text { If the form of discussion is } \\
\text { used? }\end{array}\end{array} \begin{array}{c}\text { There is almost no case that teachers participating } \\
\text { in the discussion. } \\
\text { them are the teacher speaking and the students } \\
\text { listening to. At least half of the classes are all like } \\
\text { this, even some teachers have no problem, } \\
\text { directly speak from the beginning to the end, } \\
\text { especially in the elective course. }\end{array}$ \\
\hline
\end{tabular}

Teaching method is a kind of activity way, and a kind of bilateral activity way, which is the active way that participated by both teachers and students. Its value and function is to achieve a certain teaching purpose and complete a certain teaching task. As a result, teachers in the teaching process, regardless of the specific teaching methods, should let it meet the above requirements, and focus on choosing the appropriate methods under the appropriate background, and make all the appropriate methods applied properly, to achieve the coordination with teachers, students, teaching content, and environment. People often connect teaching and cramming together, and take rigid teaching and lack of learning initiative as the inevitable result brought by the teaching method. As a matter of fact, the factor caused these ills is not the use of teaching method, but this method has not been properly applied. That is to say, the teachers do not well coordinate the relationship between teachers and students, teaching contents and environment in the process of applying methods.

\section{The Countermeasures of Promoting the Development of Students' Subjectivity in the Teaching Management of Colleges and Universities}

At present, university teaching management in China has two sides in promoting the development of students' subjectivity, which has the aspect of rational and conducive to the development of students' subjectivity, but also has the side of not conducive to and even hinder students' subjectivity. But in order to further enhance the level of teaching management in Colleges and universities of our country on the whole and play its advantage in promoting the development of students' subjectivity, we should not only pay attention to summing up the successful reform experience of the College teaching management in the past, but also attach importance to the problems that still exist in it and further innovate and improve on the basis of inheritance. This paper will be aimed at the problems of university teaching management in promoting the students' subjectivity development aspect to carry on the countermeasure discussion.

\subsection{Firmly Establish the Concept of Student' Subjectivity}

(1) Set up the subjective teaching view of the students

In the face of challenges of economic globalization and the era of knowledge economy, universities has the responsibility to cultivate the students to adapt to the innovative consciousness and innovation ability of the changing society, teach students to learn to know, learn to do, learn to live, and learn to survive, and promote the development of students' subjectivity. In order to achieve this goal, teachers must reform the traditional teaching concept of taking the input of knowledge as their task [6]. They must change from one-sided emphasis on the subject to focus on both the subject and the importance of students' experience, and regard teaching as the process for students to absorb new knowledge and recombine with their original knowledge structure and construct new knowledge structure; they are supposed to change from stressing the pre planning and objectives to pay more attention to the value of the curriculum implementation process, from singly emphasize 
teaching material to pay attention to the specific teaching situation, from the one-sided emphasis on classroom teaching form to attach importance to practice teaching and curriculum and pay attention to the special effects of students' subjective experience and the owned experience on learning process the students, respect students' individual differences, and truly teach students in accordance with their aptitude.

(2) Establish the subjective teaching management of the students

For a long time, the teaching management in Colleges and universities occupies the authority and the central position, and the teachers and students are often regarded as the passive management objects. Management status is fuzzy, and the participating behavior is not enough. Compared to teachers, students are also subject to the dual constraints of managers and teachers, lack of care for students' subjectivity. For teaching managers, they should change ignoring the teaching management and suppressing the students' subjectivity to recognize and respect the subjectivity of the student and establish the subjective teaching management. The concept of subjective teaching management is a kind of modern teaching management thought that takes respect, spreading and development of human subjectivity as its basic value orientation. The core idea of subjective teaching management concept is to admit students as the same as managers, are the main body of teaching management, which advocates the managers to strengthen guidance services, the majority of students actively participate in teaching and learning, through the power balance of teaching, learning, and managing these three parts to promote the teaching management, optimize teaching environment, and fully mobilize the enthusiasm, autonomy, and creativity of the students, so as to cultivate creative talents with good subject consciousness, subject ability and subject personality.

\subsection{Further Improve the Credit Management System and Create a Student Subject Management Atmosphere}

Implement flexible educational system. The flexible educational system is a comparatively active school register management system based on the credit system, to allow students graduating early or delaying graduation or dropping out halfway. Flexible educational system is an important part of the management of the credit system, and it is also an essential step for the transition from the academic year system to the credit system [7]. It is the reform of personnel training mode under the traditional academic year system, which is in accordance with the laws of nature of development and cultivation of talents, conducive to the school management transforming from rigid to flexible. At the same time, it also reflects the principles of teaching management that take students as the main part, which is conducive to the further expand the autonomy of students' learning and the right to choose their own development. In order to guarantee the implementation of flexible educational system, allowing students to extend and shorten the study period or stage to complete the study, perfect exemption, credit and rebuild the incentive mechanism should be established to make the system really flexible.

\section{Conclusion}

The key to promote the development of students' subjectivity lies in whether the school teaching management can provide students with a teaching environment that can stimulate students' potential and interests. In this environment, students can choose learning content and learning style, which helps the students to actively participate in learning activities to fully exert their subjectivity and initiative and manage themselves, so as to make students truly become the masters of learning and development. Based on the analysis of the existing problems of teaching management in Colleges and universities, this paper puts forward the countermeasures. It is supposed to firmly establish the subjective concept of students and further improve the credit management system. Through the research in this paper, we expect to provide reference for the teaching management in the future.

\section{References}

[1] Hayden M, Thompson J. International schools and international education: Improving teaching, management and quality[M]. Routledge, 2013. 
[2] Li Z, Shen H. Database Design on Teaching Management System Based on SQL Server[J]. 2016.

[3] Ates O. Using case studies for teaching management to computer engineering students[J]. International Journal of Business and Management, 2013, 8(5): 72.

[4] Chen D L, Chen L, Ji Q F. The Experimental Teaching Based on Hybrid Cloud Management System Research[C]//Applied Mechanics and Materials. Trans Tech Publications, 2013, 347: 2257-2260.

[5] Smith J E. Stop Doing Stupid: An Essential Requirement for Effective Teaching, Management and Leadership[J]. International Journal of Management Excellence, 2015, 5(2): 633-637.

[6] Tuo L, Bo Q. The Construction of the Evaluation System of Teaching Management Execution in Colleges and Universities [J]. Research in Higher Education of Engineering, 2012, 4: 103-109.

[7] Weijian Y. Design and Realization of Practical Teaching Management system on NET-based Platform [J]. Computer Knowledge and Technology, 2013, 9: 4013-4016. 